\title{
Performance Evaluation of Reaper--cum--Binder for Harvesting of Soybean and Rice
}

\author{
Ashutosh Tripathi, B.P. Mishra, Mithlesh Kumar*, Yogesh Singh Thakur and \\ Kipoo Kiran Singh Mahilang \\ Department of Farm Machinery and Power Engineering SVCAET \& RS, FAE, Indira Gandhi \\ Krishi Vishwavidyalaya, Krishak Nagar, Raipur, 492012, Chhattisgarh, India \\ *Corresponding author
}

\section{A B S T R A C T}

The mechanization of harvesting operation is essential to minimize the cost of harvesting, grain production cost, grain loss, turnaround time, weather risk, and to increase benefit by appropriate technology. In order to achieve the above goal, a manually controlled reaper cum- binder machine was tested and evaluate. This self-propelled reaper was operated in low $1^{\text {st }}$ gear at forward speed of $2.5 \mathrm{~km} / \mathrm{h}$. It has $1400 \mathrm{~mm}$ size of cutter bar and dropped

\section{Keywords}

Reaper, Binder,

Rice, Soybean,

Harvesting loss

Article Info

Accepted:

16 February 2018

Available Online:

10 March 2018 bundling mechanism. The testing of the machine was carried out with rice and soybean crop during Kharif season of 2012 at the research farm of Indira Gandhi Krishi Vishwavidyalaya, Raipur. This machine made crop bundles of rice weighing about 5.3. The fuel consumption of machine was varied with crop type. It was found 1.22 and 1.15 $\mathrm{lit} / \mathrm{h}$ with soybean and rice crop respectively. According the cost of operation of reaper cum- binder machine also varied according to type of crop. It was found to be 860 and $1289 \mathrm{Rs} / \mathrm{ha}$ with rice and soybean respectively. By using the reaper--cum--binder for rice crop net saving of $2223 \mathrm{Rs} / \mathrm{ha}$ and $2464 \mathrm{Rs} / \mathrm{ha}$ can be saved over Naveen and local sickle respectively. The performance of the reaper -cum- binder was also assessed and compared with manual harvesting. The reaper -cum- binder machine performed well with rice crop, whereas in soybean the bundling was not satisfactory which results higher grain loss $(21 \%)$. The actual field capacity of the reaper -cum- binder was compared with the harvesting by local sickle and Naveen sickle on rice and soybean crops. The result revealed that about 44 times higher field capacity was observed with the machine $(0.28$ $0.32 \mathrm{ha} / \mathrm{h})$ than that of traditional manual method, over local sickle $(0.00657 \mathrm{ha} / \mathrm{man}-\mathrm{h})$ and serrated Naveen sickle (0.00709 ha/ man-h).

\section{Introduction}

Harvesting of crops is one of the important agricultural operation which demands considerable amount of labour. The scarcity and high cost of labour during harvesting season are the serious problem. The total labour requirement for harvesting of cereals or pulses vary from 120-200 man-h/ha. Rice is one of major crops in India as well as in Chhattisgarh State. The total labour requirement for growing rice crop is estimated about 800 man-h/ha, excluding irrigation, bund making, transport and application of chemicals and fertilizers. Harvesting, threshing and transplanting consume about 70 
percent of the total labour requirement. Harvesting operation alone consumes 20 percent which include harvesting by sickles and bundle making (Dutt and Prasad, 2002). Traditionally, harvesting of crop is done manually using sickles, which involves 18-20 man-days per hectare. The cutting and laying in the windrow consume 65-75 percent of labour and gathering, making bundles, their transport and stacking in the field involve the rest of labour requirement. Rahman et al., (1980) reported that the performance of handoperated grain harvester is equivalent to 5-7 times that of man and design features of this machine revel bright possibilities with some minor modification, they also stated that machine represent a base for future research work.

Various kinds of grain /crop losses occur during harvesting and thereafter the field losses, including pre-harvest loss, harvesting loss, stacking losses, field storage loss and losses during on-farm transport, threshing and transport to market. These losses vary from 813 percent for most of the cereals, pulses and other crops. Sheruddin-Bukhari et al., (1991) studied the grain loss in wheat harvested by a front-mounted reaper-windrower and evaluated during field investigation at 2 sites during 1986.

The performance of the reaper-windrower was compared with that of conventional manual harvesting. At the $1^{\text {st }}$ site, the total grain losses by mechanized harvesting average $41.1 \mathrm{~kg} / \mathrm{ha}$ compared to $84.9 \mathrm{~kg} / \mathrm{ha}$ from manual harvesting. Labour requirement for machine and manual harvesting and bundling were 31.1 and $85.8 \mathrm{man}-\mathrm{h} / \mathrm{ha}$ respectively. At the $2^{\text {nd }}$ site, grain losses from machine reaping average $48.0 \mathrm{~kg} / \mathrm{ha}$ compared to an average of $139.6 \mathrm{~kg} / \mathrm{ha}$ manual harvesting. Labour requirements for machine and manual harvesting were 28.5 and $88.6 \mathrm{man}-\mathrm{h} / \mathrm{ha}$ respectively.
Mechanical harvesting of all most all cereal crops is a challenging problem in India and tropical countries. Despite the encouraging fact that India has good potential for increasing production, method of harvesting are still primitive and farmer use hand sickle for this purpose. Garg and Sharma (1991) developed a reaper-windrower with vertical conveyor belts for harvesting wheat and rice. The unit was mounted on the front of tractor, capable of harvesting $0.4 \mathrm{ha} / \mathrm{h}$, and unlike combine a harvested does not destroy the straw, which is important cattle feed. Thus they reported that compared to conventional manual harvesting with sickle the new unit reduce labour requirement by two-third. Rice harvesting by hand can required about $25 \%$ of total labour requirement of the crop. Ojha and Nath (1980) stated that the introduction of efficient harvesting aids and the equipment for the cereals crops seems to be highly necessary to minimize the time of harvesting and the grain loss suffered due to slow rate of work in process of manual harvesting. Mollah and Watt (1980) designed and developed a prototype grain crop harvesting machine. The machine cut the crops, which were planted in rows as it was pushed forwarded the cutting mechanism of the hand powered machine consisted of two counter rotating cutting discs.

The width of the machine was determined by the row spacing of the crop as it cuts a single row. Rashid et al., (1980) developed a push type harvesting machine, which was operated by human power from traction wheel. The power was transmitted to the cam wheel and then transmitted to the knife with the help of the knife actuating lever arm. Yadav and Yadav (1992) have worked on designed and development of simple, rugged oxen-drawn reaper for harvesting cereals, pulse crops and oil seed in India. An animal - drawn reaper with an engine operated cutting and conveying mechanism was designed and constructed by Singh and Singh (1995) for harvesting wheat 
and rice. Howson and Devnani (1981) studied and compared the economic feasibility of the harvester for different widths of cut and field grain yields with manual harvesting. Provided the cutting width is great enough its use is economic. The smallest practical width of cut is $1 \mathrm{~m}$ for a power operated machine. Manjunatha et al., (2009) have done a study on reducing the cost of cultivation in rice through mechanizing harvesting operations at agricultural research station, Gangavathi during Kharif, 2002 to Rabi /summer, 2004-05 and also in the farmer's field. A vertical conveyor power reaper (Kamco modelkr 120) was used for the purpose. The overall performance of the vertical conveyor reaper was quite satisfactory. The actual field capacity of the power reaper was $0.3 \mathrm{ha} / \mathrm{hr}$ with a field efficiency of $73 \%$ at an average operating speed of $3.2 \mathrm{kmph}$. The fuel consumption was $5.5 \mathrm{l} / \mathrm{ha}$. The cost of cultivation of rice crop could be reduced through mechanization of harvesting operations. Cost of mechanical harvesting was Rs.420/ha as compared Rs. 800/ha in the case of manual harvesting provided the machines are used for their maximum usage of 144 hectares in a year. Guruswamy et al., (1996) modified and evaluated a self-propelled vertical reaper -cum- windrower for harvesting safflower during 1993-94 at the Regional Research station Farm, Raichur, India, and computed with manual harvesting. Harvesting time per hectare was computed to be $10 \mathrm{~h}$ for the machine, compared with 150 ma-hours for manual harvesting. The postharvest, cutting and conveying losses for the machine were $0.05 \%, 0.47 \%$ and 0.23 (total loss of $0.75 \%$ ), respectively and for manual harvesting these values were $0.05 \%, 0.02 \%$ and $0.00 \%$ (total loss of $0.07 \%$ ), respectively. Prabhakar et al., (2000) reported that a selfpropelled reaper was earlier introduced in South India for harvesting rice by CIAE-IRRI Industrial Extension Project. The Reaper was modified by reducing the height of the cutter bar knife and speed of cross conveyer belt and evaluated for harvesting soybean in Madhya Pradesh. The main objective of this paper is to study the field performance of reaper -cumbinder for harvesting of soybean and rice.

\section{Materials and Methods}

\section{Study area}

The testing was carried out during Kharif and Rabi seasons of 2012-2013 at the research farm of Indira Gandhi Krishi Vishwavidyalaya, Raipur (C.G). The IGKV farm is situated on national highway no. 6 in eastern part of Raipur city and located between $20^{\circ} 40^{\prime} \mathrm{N}$ latitude and $81^{\circ} 39^{\prime} \mathrm{E}$ longitude with an altitude of $293 \mathrm{~m}$ above mean sea level. The climate of this region is dry moist, sub humid and region receives about 1200-1400 mm rainfall annually, out of which about 88 percent is received during rainy season (June to September) and 8 percent during winter season (October to February). May is the hottest and December is coolest month of the year. The temperature during the summer months reaches as high as $48^{0} \mathrm{C}$ and drop to $6^{0} \mathrm{C}$ during December to January.

\section{Working principle of reaper--cum--binder}

The manufacturer and supplier had not supplied manual and details with the machine therefore suitability of the crop is not known however looking its design it seems that it can be used to harvest the crop of height about 80 to $110 \mathrm{~cm}$. It has reciprocating cutter bar of cutting width about $140 \mathrm{~cm}$ which get rotary motion from the engine. The cut crop material was tied into bundles by its knotting mechanism and left on the field. During harvesting of the crop the cutting unit collects the harvest crop from on both left and right side and pushes towards the middle position of machine for dropping the bundles where the 
spring and ratchet mechanism releases the bundles. For binding a rope from the bundle chamber comes through a needle and knotting mechanism makes a knot on the collected crop.

\section{Preparation of reaper-cum-binder for field Test}

After preliminary checking the field test of machine were conducted at the IGKV farm Raipur, Research Farm during Kharif and Rabi season 2012-2013 with major crop rice, soybean as shown in Table 1.

\section{Results and Discussion}

Field performance of reaper -cum- binder with rice

The reaper -cum- binder machine was run on rice (Mahamaya) at maturity stage (116 das) and moist field condition. The crop field condition shows in appendix-G. During testing all the components of the machine worked satisfactory. The detail result and discussion, performance parameters wise are given below-

\section{Working speed in rice field}

The machine was tested to harvest rice crop and operated in IGKV farm at controllable speed ranging from 2.32 to $2.52 \mathrm{~km} / \mathrm{h}$, the harvesting capacity, field efficiency, fuel consumption and losses were recorded and shown in Table 2 . The minimum field capacity $(0.294 \mathrm{ha} / \mathrm{h})$ were observed at the lowest forward speed of $2.32 \mathrm{~km} / \mathrm{h}$. Similarly at the maximum forward speed of $2.52 \mathrm{~km} / \mathrm{h}$ which was obtained at full throttle of reaper with Igear gave highest field capacity as $0.32 \mathrm{ha} / \mathrm{h}$. It is evident from the data presented in Table 2. That the variation in the speed of reaper had positive effect on the field capacity of the reaper.

\section{Actual field capacity with rice}

The performance of the machine on rice was found satisfactory and the detail as shown in Table 2. The actual field capacity of the machine was found to be $0.31 \mathrm{ha} / \mathrm{h}$ with SD 0.0097 which was considered normal and satisfactory. The field and crop condition was suitable for harvesting. The field capacity was observed in $\mathrm{I}^{\text {st }}$ gear, in the gears $\left(2^{\text {nd }}, 3^{\text {rd }}\right.$, and $4^{\text {th }}$ ) the machine was not operated. In $I^{\text {st }}$-gear no clogging was observed. However, further more field capacity $(0.32 \mathrm{ha} / \mathrm{h})$ could be achieved.

The actual field capacity of the reaper-cumbinder to harvest the rice crop was compared with the harvesting by sickle and Naveen sickle (serrated), which reveals that the maximum average actual field capacity (0.32 $\mathrm{ha} / \mathrm{h})$ was found with the reaper -cum- binder followed by the Naveen (0.00709) and local sickle (0.00657) as shown in Figure 1. The reason for this attributes the method of harvesting and speed.

The reciprocating cutter bar cut the crop with the help of serrated knife and gathering unit and a unit of oscillated assembly on both left and right side collect the harvested crop towards middle position of cutter bar of the reaper and a rope from the bundle chamber comes through a needle and knotting mechanism makes a knot on the collected bundles. The spring and ratchet mechanism releases the bundles. Whereas in case of manual harvesting by sickle, the operator has to exert force to cut the crop in bending posture, which decreases the speed of operation. Hence the speed and also the coverage area of cutting are higher in case of reaper-cum- binder. However, for the further calculation and comparison purpose the average speed $2.44 \mathrm{~km} / \mathrm{h}$ with as average field capacity $0.31 \mathrm{ha} / \mathrm{h}$ been taken into consideration. 
Table.1 Field test condition

\begin{tabular}{|c|}
\hline 1. Location \\
\hline 2. Kind of field \\
\hline 3. Type of soil \\
\hline 4. Condition of crop \\
\hline 5. Type of Crop \\
\hline 6. Variety of crop \\
\hline 7. Avg. Height of plant, cm \\
\hline $\begin{array}{l}\text { 8. Plant/tiller/ear head } \\
\text { population, } \mathrm{no} / \mathrm{m}^{2}\end{array}$ \\
\hline 9. Avg. panicle length \\
\hline 10. Condition of operator \\
\hline 11. Body posture \\
\hline 12. Operator \\
\hline 13. Wedge of operator \\
\hline
\end{tabular}

\begin{tabular}{|c|c|}
\hline \multicolumn{2}{|c|}{ IGKV farm } \\
Medium Land \\
Sandy Clay \\
\hline $\begin{array}{c}\text { Physiological Maturity } \\
\text { Rice } \\
\text { Mahamaya }\end{array}$ \\
\hline 85 & Shysiological Maturity \\
\hline 269 & Soybean \\
\hline 24.5 & 34 \\
\hline Normal, male age 23 yr. - 40 yr. \\
Normal Sitting Position \\
One Skilled \\
175/day
\end{tabular}

Table.2 Field performance of reaper -cum- binder with rice

\begin{tabular}{|c|c|c|c|c|c|c|}
\hline Observ & $\begin{array}{c}\text { Speed of } \\
\text { ations }\end{array}$ & $\begin{array}{c}\text { Actual Field } \\
\text { capacity, } \\
\mathbf{k m} / \mathbf{h}\end{array}$ & $\begin{array}{c}\text { Field } \\
\text { efficiency, } \\
\mathbf{\%}\end{array}$ & $\begin{array}{c}\text { Fuel } \\
\text { consumption } \\
\mathbf{l} / \mathbf{h}\end{array}$ & $\begin{array}{c}\text { Harvesting } \\
\text { grain loss, } \\
\text { \% }\end{array}$ & $\begin{array}{c}\text { Labour } \\
\text { required } \\
\text { man-h/ha }\end{array}$ \\
\hline $\mathbf{1}$ & 2.43 & 0.308 & 86.44 & 1.12 & 1.028 & 3.30 \\
\hline $\mathbf{2}$ & 2.52 & 0.320 & 89.64 & 1.19 & 1.52 & 3.13 \\
\hline $\mathbf{3}$ & 2.45 & 0.311 & 87.15 & 1.20 & 1.30 & 3.21 \\
\hline $\mathbf{4}$ & 2.49 & 0.316 & 88.57 & 1.13 & 1.33 & 3.16 \\
\hline $\mathbf{5}$ & 2.32 & 0.294 & 82.53 & 1.15 & 1.84 & 3.40 \\
\hline Mean & 2.44 & 0.310 & 86.87 & 1.158 & 1.40 & 3.24 \\
\hline S.D & 0.076 & 0.0097 & 2.72 & 0.096 & 0.299 & 0.11 \\
\hline
\end{tabular}

Table.3 Field performance of reaper -cum- binder with soybean

\begin{tabular}{|c|c|c|c|c|c|c|}
\hline Observations & $\begin{array}{c}\text { Speed of } \\
\text { operation, } \\
\mathbf{k m} / \mathbf{h}\end{array}$ & $\begin{array}{c}\text { Actual } \\
\text { Field } \\
\text { capacity, } \\
\text { ha/h }\end{array}$ & $\begin{array}{c}\text { Field } \\
\text { efficiency, } \\
\text { \% }\end{array}$ & $\begin{array}{c}\text { Fuel } \\
\text { consumption, } \\
\mathbf{l} / \mathbf{h}\end{array}$ & $\begin{array}{c}\text { Harvesting } \\
\text { grain loss, } \\
\text { \% }\end{array}$ & $\begin{array}{c}\text { Labour } \\
\text { required } \\
\text { man- } \\
\text { h/ha }\end{array}$ \\
\hline $\mathbf{1}$ & 3.1 & 0.37 & 83.35 & 1.15 & 19.65 & 2.66 \\
\hline $\mathbf{2}$ & 3.15 & 0.38 & 84.7 & 1.21 & 19.82 & 2.62 \\
\hline $\mathbf{3}$ & 2.95 & 0.35 & 79.32 & 1.3 & 22.09 & 2.8 \\
\hline $\mathbf{4}$ & 2.89 & 0.34 & 77.7 & 1.13 & 22.98 & 2.85 \\
\hline $\mathbf{5}$ & 3.11 & 0.37 & 83.62 & 1.35 & 21.93 & 2.65 \\
\hline Mean & 3.04 & 0.36 & 81.74 & 1.228 & 21.29 & 2.72 \\
\hline S.D & 0.11 & 0.013 & 3.04 & 0.035 & 1.48 & 0.102 \\
\hline
\end{tabular}


Table.4 Economics of self-propelled reaper -cum- binder for rice and soybean

\begin{tabular}{|c|c|c|c|c|c|c|c|c|c|}
\hline \multirow[t]{2}{*}{$\begin{array}{l}\text { S. } \\
\text { No. }\end{array}$} & \multirow[t]{2}{*}{$\begin{array}{c}\text { Harvesting } \\
\text { Machine/method }\end{array}$} & \multicolumn{2}{|c|}{$\begin{array}{l}\text { Labour } \\
\text { required, } \\
\text { man-hr/ha }\end{array}$} & \multicolumn{2}{|c|}{$\begin{array}{c}\text { Cost of } \\
\text { operation, } \\
\text { Rs/hr }\end{array}$} & \multicolumn{2}{|c|}{$\begin{array}{l}\text { Harvesting \& } \\
\text { binding cost, } \\
\text { Rs/ha }\end{array}$} & \multicolumn{2}{|c|}{$\begin{array}{c}\text { Additional } \\
\text { expenditure, } \\
\text { Rs/ha }\end{array}$} \\
\hline & & Rice & Soybean & Rice & Soybean & Rice & Soybean & Rice & Soybean \\
\hline 1 & $\begin{array}{l}\text { Reaper -cum- } \\
\text { Binder }\end{array}$ & 3.22 & 2.72 & 267 & 267 & 860 & 1289 & --- & --- \\
\hline 2 & $\begin{array}{l}\text { Naveen Sickle } \\
\quad \text { (serrated) }\end{array}$ & 141 & 143 & 21.87 & 21.87 & 3083 & 3127 & 2223 & 1838 \\
\hline 3 & Local Sickle & 152 & 160 & 2187 & 21.87 & 3324 & 3499 & 2464 & 2210 \\
\hline
\end{tabular}

Fig.1 Average effective field capacity of different harvesting methods of rice

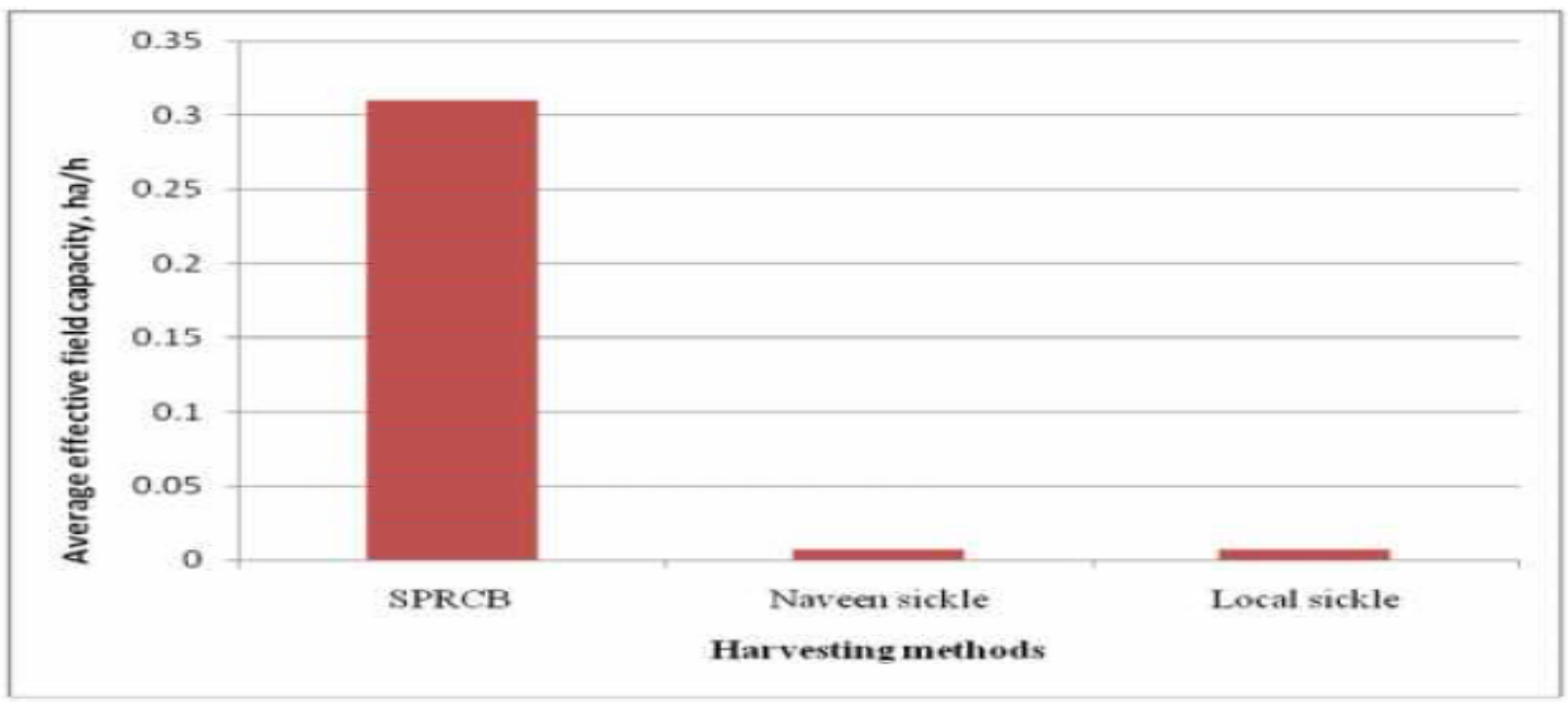

Fig.2 Average energy consumption of different harvesting methods of rice

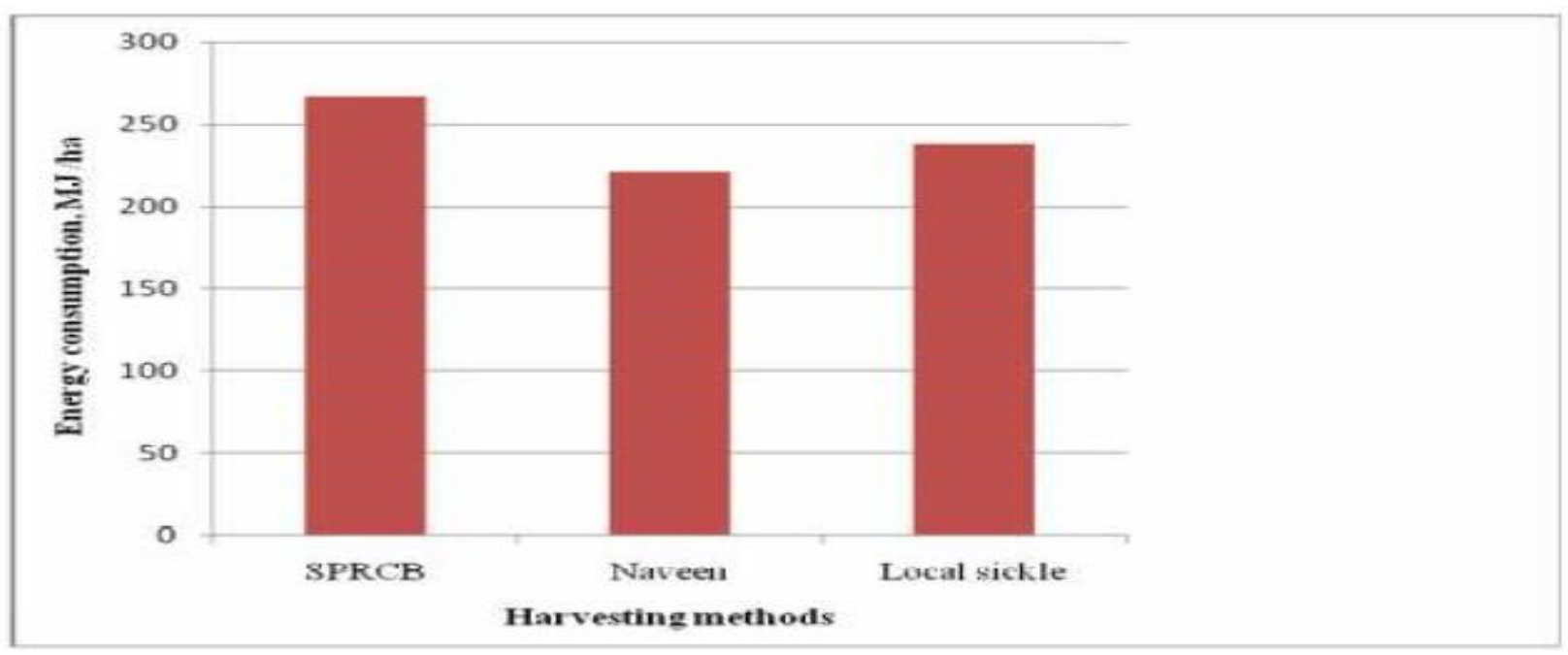


Fig.3 Average effective field capacity of different harvesting methods of soybean

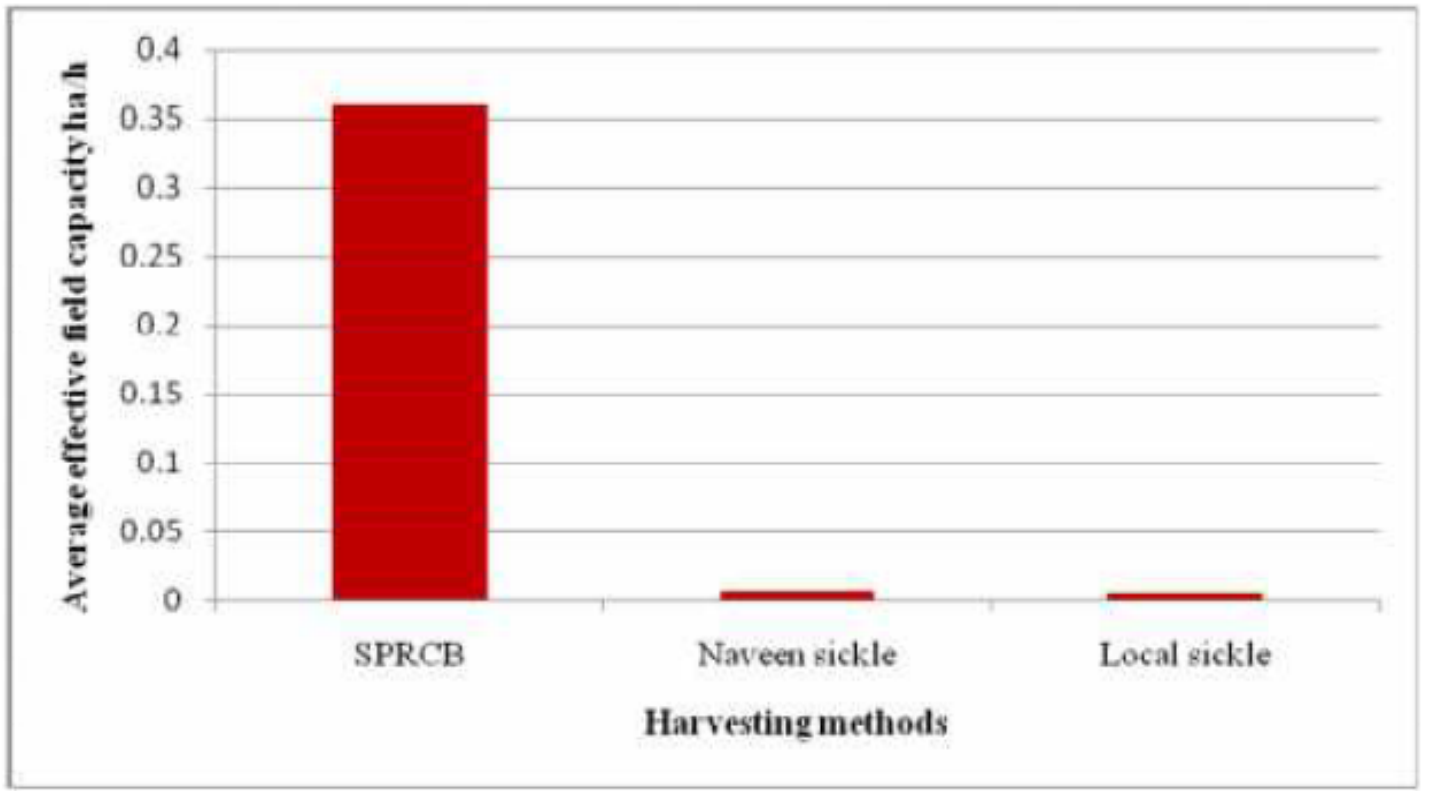

Fig.4 Economics of self-propelled reaper -cum- binder for rice and soybean

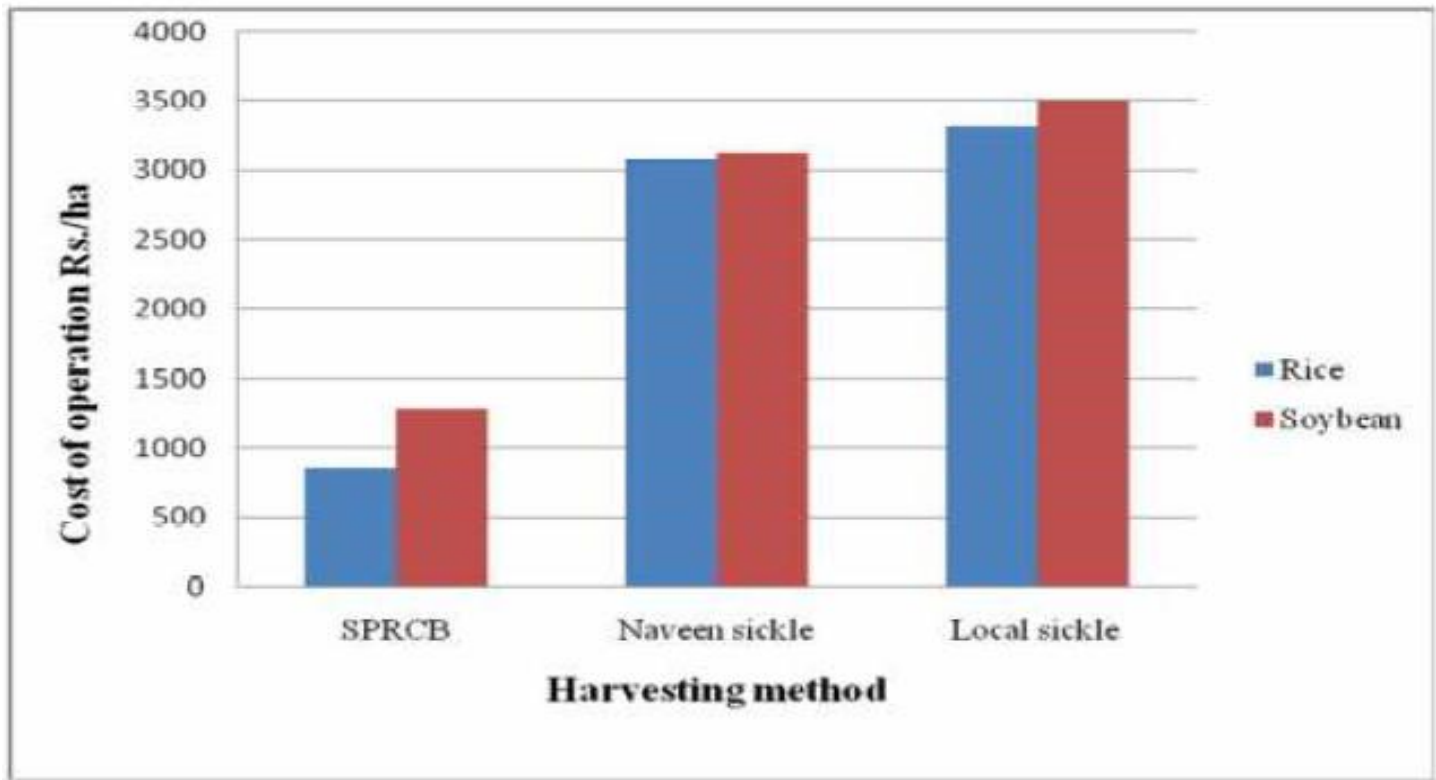

\section{Labour requirement}

The labour requirement in term of women$\mathrm{h} / \mathrm{ha}$ was calculated for the harvesting of. The labour requirement for harvesting by local sickle, Naveen sickle and reaper -cumbinder, were found as $152 \mathrm{man}-\mathrm{h} / \mathrm{ha}, 141$ man-h/ha and 3 man-h/ha respectively. This showed that use of reaper -cum- binder saved labour to a substantial extent. Dependence on uncertain labour availability in rural areas in now days, creates a big problem to the farmers. Therefore the self-propelled reaper cum- binder would prove boon to the farmer 
under such condition. The labour requirement of reaper -cum- binder for harvesting of rice is shown in Table 2.

\section{Fuel consumption}

Fuel consumption in litre per hour was measured by the fuel tank top fill method. Average fuel consumption of reaper -cumbinder during harvesting operation of rice was recorded as $1.158 \mathrm{lit} / \mathrm{h}$.

\section{Energy consumption}

The energy consumption during rice harvesting operation for reaper -cum- binder depicted in Figure 2. It reveals that the maximum energy consumed 267.5 MJ /ha was recorded in case of self-propelled reaper cum- binder under local stickle followed by $238 \mathrm{MJ} / \mathrm{ha}$ and Naveen sickle $221 \mathrm{MJ} / \mathrm{ha}$. Reaper -cum- binder consumed more energy than the local and Naveen sickle this is due to combination of machine fuel and man energy for operating a reaper.

\section{Field performance of reaper-cum-binder} with soybean

The reaper -cum- binder machine was run on Soybean (JS 97-52) at maturity stage (123 das) and moist field condition. The performance of the machine with soybean is shown in Table 3 and Figure 3. It was found not satisfactory, because during harvesting the crop collecting fork on both left and right side could not collect the harvested crop towards the middle position of binding unit, this was happen due to more height of fork from the ground. Cutter bar also not found suited to the soybean plant height and thus maximum number of plant remains un-harvested.

The quality of work was evaluated with the traditional manual method. In case of selfpropelled reaper -cum- binder the harvesting loss of soybean were found comparatively more (about 21\%), than the traditional method of harvesting $(<2 \%)$, looking to losses this can be said to be not suitable for soybean. So that reaper -cum- binder not worked satisfactory for harvesting soybean.

\section{Cost economics of the operation of reaper - cum- binder}

An economical cost of self-propelled reaper cum- binder and traditional methods of harvesting of crop (with local and Naveen sickles) are shown in Table 4 and Figure 4. The machine self-propelled reaper -cumbinder on the basis of the economics approach to suit the small and medium farmers. The cost of harvesting of rice was found maximum with local sickle (3324 Rs/ha), followed by Naveen sickle (3083 Rs/ha) whereas the lowest cost was recorded with the reaper -cum- binder (860 Rs/ha). Therefore net saving of Rs 2464 /-per hectare is recorded with the self-propelled reaper -cumbinder over traditional manual harvesting.

The cost of harvesting of soybean was found maximum with local sickle (3499 Rs/ha), followed by Naveen sickle (3127 Rs/ha) whereas the lowest cost was recorded with the reaper -cum- binder (1289 Rs/ha). Therefore net saving of Rs 2210 /-per hectare is recorded with the self-propelled reaper -cumbinder over traditional manual harvesting, but the cost of harvesting of soybean was found more than rice.

The reaper performed satisfactory. It was found suitable for harvesting rice and soybean crop it gave satisfactory level of field capacity, harvesting losses and cost of operation. Thus on the basis of information secured throughout the study the following conclusion could be inferred. The actual field capacity of the reaper-cum-binder to harvest the rice crop was compared with the 
harvesting by sickle and Naveen sickle (serrated), Which reveals that the maximum actual field capacity $(0.31 \mathrm{ha} / \mathrm{h})$ was found with the reaper -cum- binder followed by the Naveen (0.00709) and local sickle (0.00657). The average field efficiency of the reapercum-binder was found to be 86 per cent and the labour requirement for harvesting by local sickle and reaper-cum-binder, was found as $152 \mathrm{man}-\mathrm{h} / \mathrm{ha}, 141 \mathrm{man}-\mathrm{h} / \mathrm{h}$ and $3 \mathrm{man}-\mathrm{h} / \mathrm{ha}$ respectively. Harvesting loss of rice were found comparatively more (about $1.2 \%$ ), than the traditional method of harvesting $(<1 \%)$ was found. The performance of the machine with soybean was found not satisfactory. The harvesting loss of soybean were found comparatively more (about 21\%), than the traditional method of harvesting $(<2 \%)$. Reaper-cum-binder consumed more energy (267 MJ/ha) than the local (238 MJ/ha) and Naveen (221 MJ/ha) sickle this is due to combination of machine fuel and man energy for operating a reaper. Reaper-cum-binder consumed more energy (267 MJ/ha) than the local (238 MJ/ha) and Naveen (221 MJ/ha) sickle this is due to combination of machine fuel and man energy for operating a reaper.

\section{References}

Dutt, P. and Prasad, J. (2002). Modification and evaluation of self-propelled reaper for harvesting soybean. AMA. 3:43-46.

Garg, I. K. and Sharma, V. K. (1991). Tractor operated vertical conveyor reaperwindrower. Indian farming. 40 (11): 32-36.

Guruswamy, T., Desai, S. R., Veeranagouda, M. and Barker, R. D. (1996). Performance evaluation of vertical conveyor reaper windrower. Karnataka J. Agric.Sci. 9(1): 102-105.

Howson, D. F. and Devnani, R. S (1981). A width-of-cut analysis of a vertical conveyor cereal reaper for Indian farm. AMA. 23 (3): 9-14.

Manjunatha, M. V., Masthana, B. G., Reddy, S. D., Joshi, and V. R. (2009). Field performance evaluation on vertical conveyor rice reaper, Karnataka J. Agric. Sci, 22(1): 140-142.

Mollah, M. M. R. and Watt, C. D. (1980). A novel grain crops harvester for Bangladesh. Land and water use, Dodd and Grace. 2007-2013.

Ojha, T. P. and Nath S. (1980). Studies on harvesting of crop minimizing harvest and post-harvest losses. Bulletin on harvest and post-harvest technology (ICAR) Scheme. IIT Kharagpur. 4-9

Prabhakar D. J. and Prasad, J. 2000. Modification and evaluation of a self-propelled vertical conveyor reaper for harvesting soybean. AMA. 31(3): 43-46.

Rahman, S., Sanajpati, J. N. and Mohama, A. R. (1980). Design and development of hand operated grain harvester. AMA. 3 (4): 7980.

Rashid, M. A., Rahman, S. and Sanajpati, J. N. (1980). Design and development of handoperated grain harvester. AMA. 11(1): 7980.

Sheruddina- Bukhari, Mughal, A. Q., Baloch, J. M. and Malik, R. J. (1991). Grain losses in wheat harvested by tractor front mounted reaper-windrower, AMA. 22(3): 15-20.

Singh, T. P. and Singh, B. (1995). Design and development of an animal drawn, engine operated reaper. AMA. 26(2): 29-34.

Yadav, R. N. S. and Yadav, B. G. (1992). Design and development of CIAE bullock drawn reaper. $A M A$. 23(2): 43-51.

\section{How to cite this article:}

Ashutosh Tripathi, B.P. Mishra, Mithlesh Kumar, Yogesh Singh Thakur and Kipoo Kiran Singh Mahilang. 2018. Performance Evaluation of Reaper--cum--Binder for Harvesting of Soybean and Rice. Int.J.Curr.Microbiol.App.Sci. 7(03): 1754-1762.

doi: https://doi.org/10.20546/ijcmas.2018.703.207 